\title{
Xylem traits in European beech (Fagus sylvatica L.) display a large plasticity in response to canopy release
}

\author{
Estelle Noyer ${ }^{1} \cdot$ Barbara Lachenbruch $^{2} \cdot$ Jana Dlouhá $^{1} \cdot$ Catherine Collet $^{1}$. \\ Julien Ruelle $^{1} \cdot$ François Ningre $^{1} \cdot$ Meriem Fournier $^{1}$
}

Received: 19 October 2016 / Accepted: 10 April 2017 /Published online: 1 June 2017

(C) INRA and Springer-Verlag France 2017

\begin{abstract}
- Key message The position of trees in the canopy impacts xylem structure and its inter-annual variation. After canopy release, the increase in the hydraulic conductivity of growth rings was driven by an increase in radial growth in large trees, and by both an increase in radial growth and changes in xylem structure in saplings.

- Context Forest canopies are frequently subjected to disturbances that allow understory trees to access the upper canopy. The effect of canopy release on xylem anatomy has been assessed in juvenile trees and saplings, while the potential acclimation of larger trees remains poorly documented.
\end{abstract}

\section{Handling Editor: Marcus Schaub}

Contribution of the co-authors

Estelle Noyer collected the data, ran the data analysis and was the main writer.

Barbara Lachenbruch, Jana Dlouha, Catherine Collet and Meriem Fournier contributed to the discussions and to the writing.

Julien Ruelle developed image analysis tools and contributed to the discussions.

François Ningre designed the Grand Poiremont forest experiment.

Electronic supplementary material The online version of this article (doi:10.1007/s13595-017-0634-1) contains supplementary material, which is available to authorized users.

Estelle Noyer

noyer.estelle@gmail.com

Barbara Lachenbruch

barb.lachenbruch@oregonstate.edu

Jana Dlouhá

jana.dlouha@inra.fr

Catherine Collet

catherine.collet@inra.fr
- Aims We estimated the potential hydraulic conductivity of growth rings in large understory trees compared to overstory trees, and evaluated the responses to canopy release in large trees and in saplings.

- Methods We recorded radial growth, wood density, and vessel structure in beech trees according to their position within the canopy and their size. Xylem traits were followed during 6 years after canopy release for large trees, and during 2 years for saplings. Vessel diameter and frequency as well as ring area were used to compute the potential annual ring hydraulic conductivity.

- Results Large understory trees displayed lower radial growth increments and lower potential annual ring hydraulic conductivity than overstory trees. After canopy release, potential annual ring hydraulic conductivity increased in large trees, due exclusively to increased radial growth without any change in specific hydraulic conductivity. It increased in saplings due to both increased radial growth and increased specific conductivity.

- Conclusion Tree size impacted xylem structure and resulted in plasticity of the potential hydraulic conductivity of the annual tree ring following canopy release.

Keywords Xylem anatomy $\cdot$ Vessel $\cdot$ Potential hydraulic conductivity $\cdot$ Radial growth $\cdot$ Wood density

Julien Ruelle

julien.ruelle@inra.fr

François Ningre

francois.ningre@inra.fr

Meriem Fournier

meriem.fournier@agroparistech.fr

1 LERFoB, INRA, AgroParisTech, F-54000 Nancy, France

2 Department of Forest Ecosystems \& Society, Oregon State University, Corvallis, OR 97333, USA 


\section{Introduction}

Trees face changing environments throughout their lifetime because their locations may experience environmental change, and also because they sample locations differently as they grow. By examining modifications in stem structure such as microclimate changes, ecophysiological responses may be uncovered. The present work focuses on plasticity in xylem traits of stems in response to tree position within the canopy. European beech (Fagus sylvatica L.), a diffuse-porous species with a wide functional sapwood area (Gasson 1985), was chosen as the model species because of its known plasticity to growth conditions (Stojnic et al. 2013; Eilmann et al. 2014; Schuldt et al. 2016). It is a shade-tolerant species that can survive under a high level of inter-tree competition, and can rapidly respond to changes in canopy structure and local irradiance (Lemoine et al. 2002a, 2002b; Caquet et al. 2009a).

The potential specific hydraulic conductivity at tissue level $\left(\mathrm{K}_{\mathrm{S}}\right)$ is a function of vessel diameter and frequency (Tyree and Zimmermann 2002). Slight modifications in vessel diameter have a large impact on hydraulic properties (Gartner 1991; Badel et al. 2015). Trees can also alter the conductivity in the whole stem by increasing sapwood width or by increasing the width of the new growth rings (Maherali et al. 1997), independently of any change in $\mathrm{K}_{\mathrm{S}}$.

Understory trees grow under lower irradiance levels, lower wind speeds and lower extremes in air temperature and vapor pressure deficit(VPD) (Parker etal. 1995; Aussenac 2000). They are shorter, exhibit smaller stem diameters, narrower annual growth increments, and lower sapwood area (Nicolini et al. 2001; Löf et al. 2005; Petritan et al. 2009; Klopcic and Boncina 2010; Fajardo 2016), and may have access to less water than overstory trees (Bréda et al. 1995). While modifications in xylem traits reflect tree acclimation (Fonti et al. 2010; Anderegg and Meinzer 2015), there is little literature on xylem anatomy and function in overstory vs understory trees from temperate forests. Most studies focus on sunexposed and shaded branches on the same individual (Lemoine et al. 2002a; Gebauer et al. 2014), which is not representative of acclimation at tree level. Some studies suggest that because of lower access of understory trees to water, it would be to their advantage to display a larger resistance to soil water shortage than overstory trees. And because of lower irradiance (Hacke 2014), shorter path length (Preston et al. 2006), and possibly lower dry growth conditions (Hajek et al. 2016), smaller vessels might occur in understory trees. However, other studies suggest that the lower evaporative demand and shorter stem could lead to lower tension in the xylem column of understory trees (Granier et al. 2000) and, therefore, to wider vessels.

Another case in which xylem plasticity could play an important role is after understory trees are released from inter-tree competition. Natural or anthropogenic disturbances periodically affect most forest ecosystems (Rentch et al. 2010), and provide the opportunity for understory trees to reach the canopy (Webster and
Lorimer 2005). Such released understory trees then have to cope with severe and sudden changes in their environment. To our knowledge, the acclimation process of stem xylem after canopy release, including the timing and nature of changes in xylem traits, has not been fully characterized. Various studies analyzing xylem traits of released angiosperm trees focused on the instant response to canopy release. While some authors observed an increase in vessel diameter and a decrease in vessel frequency (Hoffmann and Schweingruber 2002; Caquet et al. 2009a), others did not observe such changes (Maherali et al. 1997). Moreover, enhanced radial growth following canopy release has been repeatedly observed (Collet et al. 2001; Hartmann and Messier 2011). Large-diameter trees have a greater potential than smaller trees to increase stem conductivity through enhanced radial growth, due to wider annual rings (Caquet et al. 2009b; Klopcic and Boncina 2010) and larger relative basal area increments. Therefore, the relative importance of changes in xylem structure vs changes in ring width for altering water transport capacity may depend on tree size.

The study focuses on the response of stem xylem traits to tree position within the canopy and to canopy release, assessed in experimental sites with either large or small beech trees. We recorded xylem structure and growth increment to reconstruct hydraulic conductivity of tree-rings in the past. Such a retrospective approach does not allow either any direct measurement of stem conductivity or the ability to access past sapwood width or total stem conductance. Thus, we concentrated on changes in potential hydraulic conductivity at tree ring level. We tested the following hypotheses:

- (H1) understory trees display a xylem structure with smaller vessel diameter and higher vessel frequency;

- $(\mathrm{H} 2)$ because of lower year-to-year variation in the microenvironment, understory trees exhibit a more stable xylem structure from year to year than overstory trees;

- (H3) after canopy release, understory trees increase the conducting area and change the number and size of vessels, and attain similar potential annual ring hydraulic conductivity than overstory trees within a few years;

- (H4) after canopy release, small trees display larger adjustments in xylem anatomy, in addition to radial growth as a basis for increased potential ring conductivity, than large trees which have larger tree-ring sections.

\section{Material and methods}

\subsection{Study sites and plant material}

\subsubsection{Large trees}

The site for large trees was a 13-ha stand in a managed forest in north-eastern France $\left(47.9507^{\circ} \mathrm{N}, 6.3857^{\circ} \mathrm{E}\right.$, alt: $\left.470 \mathrm{~m}\right)$. 
The soil was dystric to hyperdystric cambisol with a luvic layer between the A and S horizons (IUSS Working Group WRB 2014). Meteorological data were recorded from 2001 to 2013 from the Aillevillers-et-Lyaumont weather station (French National Climatic Network, Météo-France) $5 \mathrm{~km}$ from the stand. Over that period, the mean annual temperature was $10.3{ }^{\circ} \mathrm{C}$ (Online Resource 1). The mean annual precipitation was 1,218 mm. During 2003 and 2011, years with very dry summers in Europe, temperatures were slightly higher and precipitation slightly lower than long-term means.

The broadleaved stand had formerly been managed as a coppice-with-standards. In 1955-1956, however, the stand was thinned and converted to a high forest. Records show it was further thinned between 1956 and 1995, but the years of thinning were not recorded. After 1995, there was no further thinning. In 2006, the stand was dominated by Fagus sylvatica L. (basal area: $21 \mathrm{~m}^{2} \mathrm{ha}^{-1}$ ) with another $5.5 \mathrm{~m}^{2} \mathrm{ha}^{-1}$ of Quercus spp., Fraxinus excelsior L., Acer pseudoplatanus L., Carpinus betulus L., Betula spp., Abies alba Mill, and Picea abies L. (H) Karst. Stand density was 513 stems ha ${ }^{-1}$ and the mean height of the overstory trees was $31.6 \mathrm{~m}$.

During fall 2007, we selected a sample of 42 understory beech trees distributed throughout the stand and at least $18 \mathrm{~m}$ from one another. The trees originated from seeds, and grew under closed canopy or in small gaps. Sample trees met the following criteria: DBH was 7.5 to $17.5 \mathrm{~cm}$, stems were unforked, leaned $<11^{\circ}$, had fewer than 25 epicormic branches (sensu Colin et al. 2012) along the lowest $4 \mathrm{~m}$ of stem, and had no visible injury, spiral grain, canker, or top dieback. The sample trees were then split into two subsamples with similar mean values for diameter, height, and relative vertical crown length (Table 1). During winter 2007-2008, one subsample was released by a thinning that removed the competing trees in a 12-m radius around each target tree (hereafter referred to as "released" trees) and the other subsample of trees was left unreleased ("suppressed" trees) (Ningre et al. 2011).

Five overstory, healthy, and relatively straight beech trees were also selected. They were later found to be among the oldest canopy trees of the stand (Table 1).

\subsubsection{Saplings}

The site for the saplings $\left(49.0778^{\circ} \mathrm{N}, 6.0172^{\circ} \mathrm{E}\right)$ (Caquet et al. 2009b; Caquet et al. 2009a) is at a distance of about $150 \mathrm{~km}$ from the large tree site and at a similar altitude $(300 \mathrm{~m})$. The soil is a calcisol (40-60 cm depth). Mean annual temperature is $10.1{ }^{\circ} \mathrm{C}$ and annual precipitation is $745 \mathrm{~mm}$ (French National Climatic Network, Météo-France).

The stand was formerly a broadleaved coppice-withstandards converted to a high forest during the 1960s. In 1999, a storm created scattered canopy gaps. In 2006, the forest canopy was mainly composed of $F$. sylvatica, Acer pseudoplatanus L., Acer platanoides L., Carpinus betula L. and Quercus spp.

During January 2005, four advanced regeneration patches were selected under closed canopy and at least $300 \mathrm{~m}$ from one another. Canopy gaps of 500 to $1,900 \mathrm{~m}^{2}$ were created by removal of all overstory trees above two patches (leaving the "released" understory saplings) and the two other patches were left unthinned ("suppressed" saplings). Two 0.5- to 1$\mathrm{m}$-tall beech saplings were selected for measurement in each patch. Additionally, four beech saplings were selected in gaps that had been created by the 1999 storm ("acclimated" saplings) (Table 1). During summer 2005, relative irradiance (with respect to the irradiance above canopy) was estimated above each selected sapling with hemispherical photography. It reached, on average, 5, 31, and $60 \%$ for the suppressed, released, and acclimated saplings respectively (Caquet et al. 2009b).

\subsection{Measurements}

\subsubsection{Large trees}

The released and suppressed understory trees were felled during March 2014, 6 years after canopy release. Two 5-cm-thick disks were collected at a height of $1.30 \mathrm{~m}$ from each tree and wrapped in plastic film. The first disk, used for anatomical measurements, was stored at $4{ }^{\circ} \mathrm{C}$ immediately after

Table 1 Sample tree characteristics (number of trees, age, and tree height range, mean \pm standard error of stem diameter and cross-section area) in 2013 for large trees and in 2006 for saplings

\begin{tabular}{|c|c|c|c|c|c|c|}
\hline & \multicolumn{3}{|l|}{ Large } & \multicolumn{3}{|l|}{ Sapling } \\
\hline & Overstory & $\begin{array}{l}\text { Understory } \\
\text { suppressed }\end{array}$ & $\begin{array}{l}\text { Understory } \\
\text { released }\end{array}$ & Acclimated & $\begin{array}{l}\text { Understory } \\
\text { suppressed }\end{array}$ & $\begin{array}{l}\text { Understory } \\
\text { released }\end{array}$ \\
\hline Number of trees & 5 & 21 & 21 & 4 & 4 & 4 \\
\hline Age & $83-117^{*}$ & $54-108$ & & $11-18$ & & \\
\hline Tree height (m) & $27.7-31.6$ & $12.4-25.1$ & & $0.5-1.0$ & & \\
\hline Stem diameter $(\mathrm{cm})$ & $52.60 \pm 0.91$ & $12.13 \pm 0.52$ & $14.98 \pm 0.57$ & $0.92 \pm 0.48$ & $0.50 \pm 0.04$ & $0.74 \pm 0.07$ \\
\hline Stem cross-section area $\left(\mathrm{cm}^{2}\right)$ & $2150.81 \pm 150.49$ & $132.93 \pm 16.01$ & $181.29 \pm 13.68$ & $0.68 \pm 0.11$ & $0.20 \pm 0.03$ & $0.44 \pm 0.08$ \\
\hline
\end{tabular}

* at breast height $(1.30 \mathrm{~m})$ 
harvesting. Using growth stress indicator measurements (Fournier et al. 1994), we identified the radial position of expected tension-wood (Purba et al. 2015). Radii perpendicular to the tension-wood zone and without knots were considered to be normal wood. A radial strip $(0.5 \mathrm{~cm} \times 1.8 \mathrm{~cm}, \mathrm{~T} \mathrm{x} \mathrm{L})$ was then cut in the normal wood zone and divided into successive 1.5 -cm-long segments. Each segment was embedded in successive polyethylene glycol baths $(30 \%, 50 \%$, and $100 \% \mathrm{w} / \mathrm{v}$ ). Twelve- $\mu \mathrm{m}$-thick cross-sections were cut from each segment with a sliding microtome. They were doublestained with a specific staining procedure as follows. They were first stained for $1 \mathrm{~min}$ in aqueous Safranin $(1 \% \mathrm{w} / v)$, treated with hydrochloric alcohol for $1 \mathrm{~min}$, rinsed with distilled water, then stained with Astra blue $(1 \% \mathrm{w} / \mathrm{v})$ for $5 \mathrm{~min}$, rinsed with distilled water, and dehydrated sequentially with $96 \%$ and absolute ethanol. Finally, the sections were mounted on glass slides in Histolaque LMR○. Each section was then imaged at $\times 10$ magnification with a digital camera (Sony $\mathrm{XCD}-\mathrm{U} 100 \mathrm{CR}$ ) through a light microscope (Zeiss AxioImagerM2) with image acquisition software (Archimed software, Microvision Instruments, France). For each image, three to six sectors bounded by rays were defined per ring to collect data related to vessel number and geometry. Sectors typically contained 25 to 200 vessels.

The second disk was used for ring width and wood density measurements. It was stored at $-20^{\circ} \mathrm{C}$ immediately after harvest. After disks were sanded, four perpendicular radii were imaged by digital camera. On each radius, the width of each ring $(\mathrm{RW}, \mathrm{mm}$ ) from pith to bark was measured to a precision of $0.01 \mathrm{~mm}$, by image analysis using TSAP-Win (Rinntech, Germany).

One of the normal wood radii was used for wood density measurements. A radial strip $(2.5 \mathrm{~cm} \times 5 \mathrm{~cm}, \mathrm{~T} \mathrm{x} \mathrm{L})$ was cut and conditioned for 1 month at $12 \%$ relative humidity at ambient temperature. A radial slice $\left(1.0 \times 0.2 \mathrm{~cm}^{2}, \mathrm{~T} \times \mathrm{L}\right)$ was then cut for X-ray micro-densitometry measurements with a microfocus X-ray source (Hamamatsu L9181-02130 kV) and a digital X-ray detector (Varian PaxScan 4030R). Pixel size varied between 20 to $30 \mu \mathrm{m}$. The Crad and Cerd software suite was used to compute radial wood density (WD, $\mathrm{kg}$ $\mathrm{m}^{-3}$ ) profiles (Mothe et al. 1998).

The selected overstory trees were sampled with an increment borer. In June 2015, two 5-mm-diameter cores were collected at $1.30 \mathrm{~m}$ in height. Cores were stored at $4{ }^{\circ} \mathrm{C}$. These cores were used for anatomical and X-ray micro-densitometry measurements, using a protocol similar to the one used for understory trees. Ring widths for the overstory trees were estimated from X-ray data.

\subsubsection{Saplings}

Understory saplings were harvested from late August to midSeptember 2006, two growing seasons after treatments had been applied. A 2- to 3-cm-long stem portion was cut from each sapling from just above ground level. It was stored at $-20{ }^{\circ} \mathrm{C}$ until it was analyzed.

A $12-\mu \mathrm{m}$-thick cross-section was then cut from each stem portion using a sliding microtome (SM2000, Leica Jung, Nussloch, Germany). Sections were double-stained as for the large trees, and mounted on slides with Canada balsam. Images were taken and analyzed as above, to measure ring width. Vessel number and geometry were measured in three to six sectors bounded by rays in each of the three most recent (youngest) growth rings.

\subsection{Data analysis}

For each tree and sapling, annual ring width and annual basal area increment $\left(\mathrm{BAI}, \mathrm{cm}^{2}\right)$ was estimated from the position data for ring boundaries, averaged over the four radii. BAI was estimated as follows:

$B A I=\pi\left(r_{1}^{2}-r_{2}^{2}\right)$

where $r_{1}$ and $r_{2}(\mathrm{~cm})$ are the average of the radii from 2 successive years.

The Hagen-Poiseuille diameter is the vessel diameter which, if multiplied by the observed vessel frequency, gives the same potential specific conductivity as the actual vessel diameter (VD) distribution. Following Steppe and Lemeur (2007), the Hagen-Poiseuille vessel diameter $\mathrm{D}_{\mathrm{HP}}(\mu \mathrm{m})$ equation was adjusted for elliptical vessel (Fig. 1) and computed as:

$D_{H P}=\sqrt[4]{\frac{1}{n} \sum_{i=1}^{n} \frac{2 a_{i}^{3} b_{i}^{3}}{a_{i}^{2}+b_{i}^{2}}}$

where $n$ is the number of measured vessels, and $a$ and $b(\mu \mathrm{m})$ are the two axes of the ellipse (maximum and minimum lumen diameter, respectively).

The potential hydraulic conductivity is the total estimated conductivity of a sample of vessels assuming that their flow is governed by the Hagen-Poiseuille equation. Potential specific hydraulic conductivity $\mathrm{K}_{\mathrm{S}}\left(\mathrm{kg} \mathrm{m}^{-1} \mathrm{~s}^{-1} \mathrm{MPa}^{-1}\right)$ was calculated as follows:

$K_{s}=\left(\frac{\pi \rho}{128 \eta}\right) \cdot D_{H P}{ }^{4} \cdot V F$

where $\eta$ is the viscosity of water $\left(1.002 * 10^{-9} \mathrm{MPa} \mathrm{s}^{-1}\right), \rho$ the density of water $\left(998.21 \mathrm{~kg} \mathrm{~m}^{3}\right), \mathrm{D}_{\mathrm{HP}}$ is the Hagen-Poiseuille vessel diameter $(\mathrm{m})$ and $\mathrm{VF}\left(\mathrm{n} \mathrm{m}^{-2}\right)$ is the mean vessel number per square meter.

The potential hydraulic conductivity for a ring $\mathrm{K}_{\text {ring }}(\mathrm{kg} \mathrm{m}$ $\mathrm{s}^{-1} \mathrm{MPa}^{-1}$ ) is estimated by:

$K_{\text {ring }}=K_{s} \cdot B A I$ 
Fig. 1 Images of large overstory (a and $\mathbf{b})$ and understory (c) trees and saplings (d). At the left of each image, ticks represent treering boundaries and the arrow the ring the first year after a release event. $V$ : vessels; $R$ : ray parenchyma. Bars: $100 \mu \mathrm{m}$
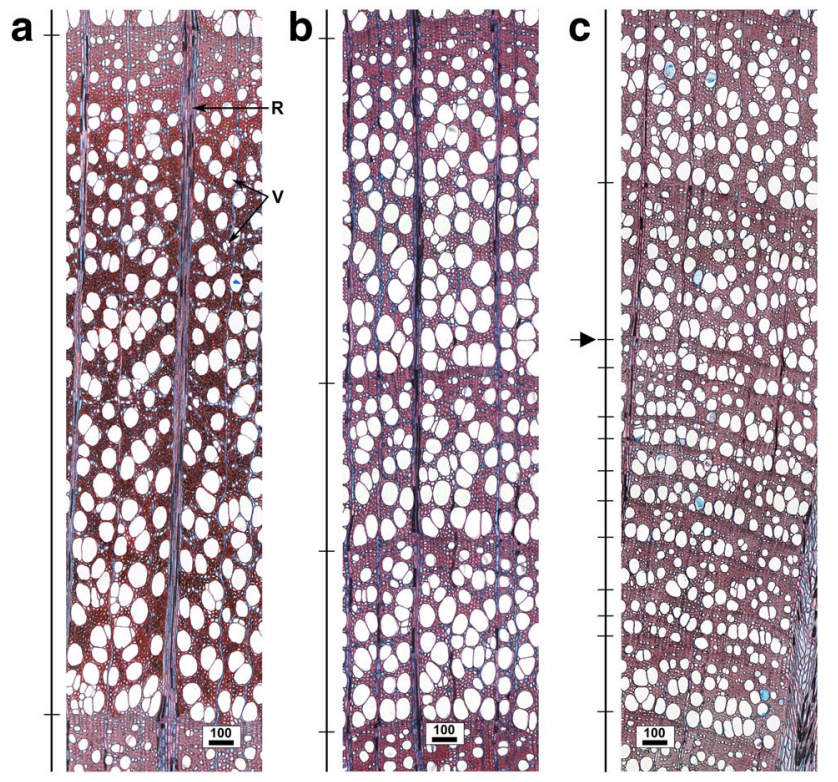

For each measured or computed trait and for each year, trees or saplings in different treatments were compared using a Kruskal-Wallis test. On large trees, if the associated $p$-value was below 0.05, a post-hoc Wilcoxon-Mann-Whitney test was made. Large trees and saplings were tested independently. All statistical analyses were performed using R software, version 3.2.3 (R Core Team 2015).

To identify the variance contribution of each factor $\left(D_{\mathrm{HP}}\right.$, $\mathrm{VF}$ and $\mathrm{BAI}$ ) to the $\mathrm{K}_{\text {ring }}$ variation, we computed variance partitioning of log transformed Eq. (5) as follows:

$$
\begin{aligned}
\operatorname{Var}\left(\log _{10} K_{\text {ring }}\right)= & \operatorname{Var}\left(4 \log _{10} D_{H P}\right)+\operatorname{Var}\left(\log _{10} V F\right) \\
& +\operatorname{Var}\left(\log _{10} B A I\right) \\
& +2 \operatorname{Cov}\left(4 \log _{10} D_{H P}, \log _{10} B A I\right) \\
& +2 \operatorname{Cov}\left(4 \log _{10} D_{H P}, \log _{10} V F\right) \\
& +2 \operatorname{Cov}\left(\log _{10} V F, \log _{10} B A I\right)
\end{aligned}
$$

The covariance factor expresses the interaction between individual factors that can be synergistic (positive value) or compensative (negative value). A covariance value close to zero means that factors are independent.

Results are presented as a relative contribution to total variance and are computed for the second year after release for understory saplings and large trees in comparison to suppressed individuals.

\section{Results}

\subsection{Large trees}

BAI of overstory trees varied widely among years (Fig. 2a) and BAI was at least 15 -fold higher in overstory than in understory trees in all years. Before the release in 2007, understory trees showed stable BAI values. After 2007, BAI of understory suppressed trees remained at $2.1 \mathrm{~cm}^{2}$ whereas, for released trees, it significantly increased until 2009 and leveled off at $14.0 \mathrm{~cm}^{2}$. However even after stabilization, BAI remained significantly lower for released than for overstory trees (Fig. 2a; Table 2).

During most years before the release, overstory trees exhibited significantly higher vessel diameter (51.9 to $56.7 \mu \mathrm{m})$ than understory trees $(40.1$ to $45.7 \mu \mathrm{m})$. After release, vessel diameter significantly increased in released trees. In 2009 and afterwards, it was 43.7 and $49.4 \mu \mathrm{m}$ in suppressed and released understory trees respectively (Fig. 2b; Table 2).

Vessel frequency was significantly higher in understory trees than in overstory trees and significantly decreased in released trees (Fig. 2d; Table 2). Wood density was not significantly lower in overstory than understory trees except during in 2004 and 2011 (Fig. 2f; Table 2). In overstory trees, wood density and BAI displayed similar inter-annual variations.

From 2002 to $2007, \mathrm{D}_{\mathrm{HP}}$ and $\mathrm{K}_{\mathrm{S}}$ were higher in overstory than understory trees $(61.7$ to $49.6 \mu \mathrm{m}, 50.6$ to $27.6 \mathrm{~kg}$ $\mathrm{m}^{-1} \mathrm{~s}^{-1} \mathrm{MPa}^{-1}$ respectively) (Fig. 2c, e; Table 2). After release, $\mathrm{D}_{\mathrm{HP}}$ showed the same trend as VD: an increase until 2009 followed by a stabilized range of values around $55.7 \mu \mathrm{m}$. Annual variations in $\mathrm{D}_{\mathrm{HP}}$ in suppressed trees were significantly lower than in released trees and overstory trees. $\mathrm{K}_{\mathrm{S}}$ fluctuated between 42.5 and $53.9 \mathrm{~kg} \mathrm{~m}^{-1} \mathrm{~s}^{-1} \mathrm{MPa}^{-1}$ in overstory trees whereas it was very stable in understory trees and did not significantly increase after release (Fig. 2e; Table 2). In all trees, $\mathrm{K}_{\text {ring }}$ showed inter-annual fluctuations similar to BAI. $\mathrm{K}_{\text {ring }}$ was significantly higher in overstory $\left(10.5 * 10^{-2}\right.$ to 23.7 $\left.* 10^{-2} \mathrm{~kg} \mathrm{~m} \mathrm{~s}^{-1} \mathrm{MPa}^{-1}\right)$ than in understory trees $\left(0.9 * 10^{-2} \mathrm{~kg}\right.$ $\mathrm{m} \mathrm{s}^{-1} \mathrm{MPa}^{-1}$ ) (Fig. 2g; Table 2). $\mathrm{K}_{\text {ring }}$ of released trees increased after release and stabilized at around $3.9 * 10^{-2} \mathrm{~kg} \mathrm{~m}$ 
Fig. 2 Mean $( \pm \mathrm{SE})$ of xylem traits $(\mathbf{a}, \mathbf{b}, \mathbf{d}, \mathbf{f})$ : basal area increment (BAI), vessel diameter (VD), vessel frequency (VF) and wood density (WD); and potential hydraulic performances (c, e, g): vessel conductivity-weight $\left(\mathrm{D}_{\mathrm{HP}}\right)$, potential specific hydraulic conductivity $\left(\mathrm{K}_{\mathrm{S}}\right)$ and ring conductivity $\left(\mathrm{K}_{\text {ring }}\right.$ ) of overstory (green) and understory suppressed (black, dotted lines) and released (yellow) large trees. The vertical dotted line shows the canopy release of understory released trees in winter 2007 2008

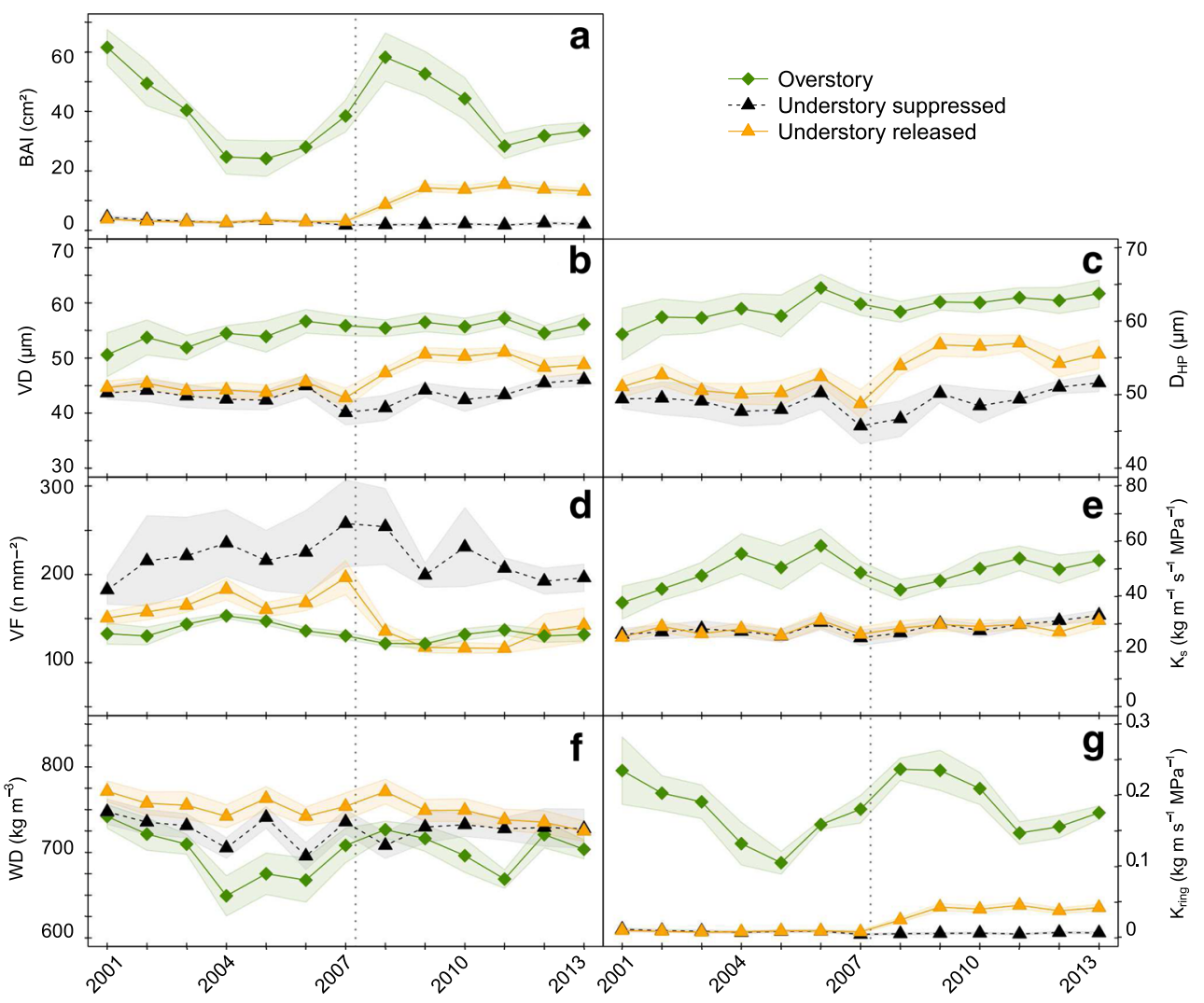

$\mathrm{D}_{\mathrm{HP}}$ increased each year in acclimated (from 24.7 to $32.6 \mu \mathrm{m}$ ) and released (from 26.3 to $33.9 \mu \mathrm{m}$ ) saplings. Suppressed saplings showed stable $\mathrm{D}_{\mathrm{HP}}$ of around $24.2 \mu \mathrm{m}$ in all years (Fig. 3b; Table 4). $\mathrm{K}_{\mathrm{s}}$ of acclimated saplings increased in 2005 (from 1.9 to $3.4 \mathrm{~kg} \mathrm{~m}^{-1} \mathrm{~s}^{-1} \mathrm{MPa}^{-1}$ ), whereas $\mathrm{K}_{\mathrm{S}}$ of released saplings increased in 2006, the second growing season after release $\left(6.5 \mathrm{~kg} \mathrm{~m}^{-1} \mathrm{~s}^{-1} \mathrm{MPa}^{-1}\right)$ (Fig. 3d; Table 4). Similar to the other measured variables, suppressed saplings had very stable values of $\mathrm{K}_{\mathrm{S}}$ (Fig. $3 \mathrm{~d}$ ). $\mathrm{K}_{\text {ring }}$ increased in all years in both acclimated and released saplings, up to $0.95 *$ $10^{-4}$ and $1.28 * 10^{-4} \mathrm{~kg} \mathrm{~m} \mathrm{~s}^{-1} \mathrm{MPa}^{-1}$ respectively (Fig. 3f; Table 4), the result of increases in $\mathrm{K}_{\mathrm{S}}$ and BAI.

In saplings, BAI contributed up to $45 \%$ to variation in $\mathrm{K}_{\text {ring }}$, whereas $\mathrm{D}_{\mathrm{HP}}$ contributed up to $38 \%$ and VF $8 \%$. The covariance between $\mathrm{BAI}$ and $\mathrm{D}_{\mathrm{HP}}$ was $83 \%,-36 \%$ between $\mathrm{D}_{\mathrm{HP}}$ and $\mathrm{VF}$, and $-38 \%$ between BAI and VF (Table 3 ).

\section{Discussion}

\subsection{Effect of tree position within the canopy on xylem traits in large trees}

In large trees, xylem structure strongly differed between understory and overstory trees, except for wood density (Fig. 2). As expected, understory trees presented a xylem structure with smaller vessel diameter and higher vessel frequency than $\mathrm{mm}^{-2}$ respectively. 


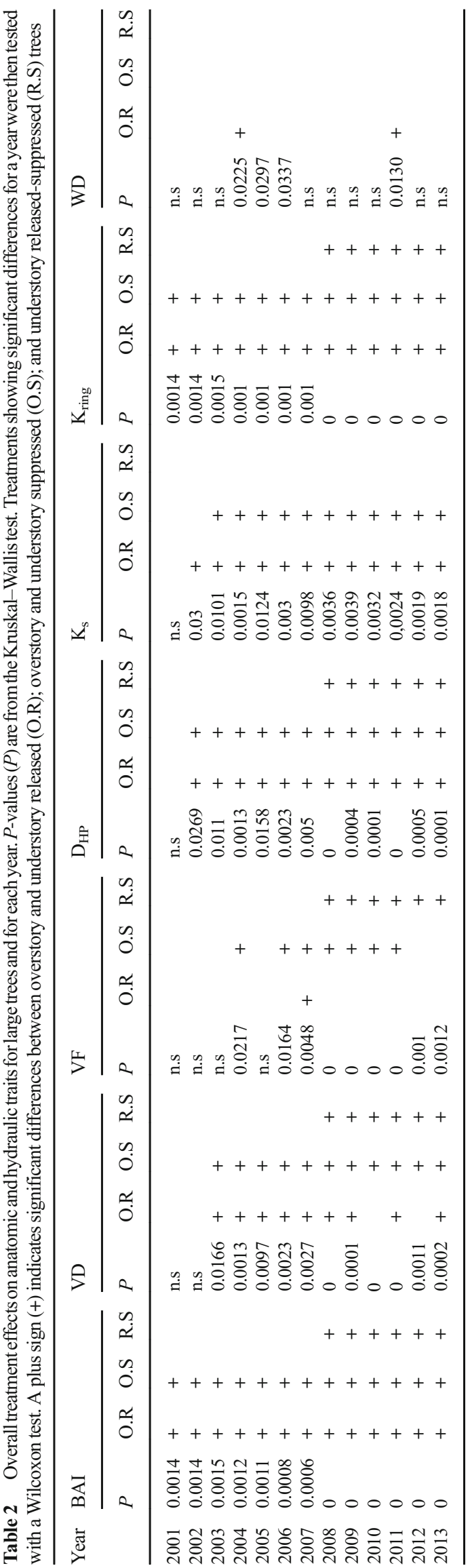

Table 3 Relative contribution (\%) of $\mathrm{D}_{\mathrm{HP}}, \mathrm{VF}$ and BAI to $\mathrm{K}_{\text {ring }}$ variance in understory released trees and saplings, 2 years after canopy release

\begin{tabular}{lllllll}
\hline & $\mathrm{D}_{\mathrm{HP}}$ & $\mathrm{VF}$ & $\mathrm{BAI}$ & $\mathrm{D}_{\mathrm{HP}}, \mathrm{BAI}$ & $\mathrm{DHP}, \mathrm{VF}$ & $\mathrm{BAI}, \mathrm{VF}$ \\
\hline Large trees & 4.32 & 4.56 & 101.10 & 41.82 & -8.88 & -42.92 \\
Saplings & 38.40 & 8.25 & 44.55 & 82.72 & -35.59 & -38.34 \\
\hline
\end{tabular}

overstory trees (Hypothesis 1 ). Understory trees are simultaneously subjected to lower soil water supply (related to higher inter-tree competition and lower root biomass, Delagrange et al. 2004; Matjaž and Primož 2010) and to lower potential evapotranspiration (related to lower VPD, lower irradiance, and lower leaf area, Barigah et al. 2006; Klopcic and Boncina 2010; Hajek et al. 2016) than overstory trees. Schuldt et al. (2016) reported that the reduction of water availability generated narrower vessels. In our case, tree water availability was limited by soil conditions and could have been one of the drivers of reduced xylem vessel size in understory trees.

The consequences of these anatomical differences coupled with stem diameter differences would be a lower potential for water transport through the annual ring in understory trees compared to overstory trees. As stated in previous studies (McCulloh et al. 2010; McCulloh et al. 2015), a small stem diameter induces reduced potential specific conductivity and potential ring conductivity, although xylem structure adjustments that resulted in smaller $\mathrm{D}_{\mathrm{HP}}$ (through vessel diameter and vessel frequency) also contributed. Furthermore, the differences in xylem anatomy of understory vs overstory trees may be also related to the longer water path length from roots to canopies of overstory trees (Preston et al. 2006; Fan et al. 2012).

As expected, the growth and wood traits displayed smaller inter-annual variations in understory than overstory trees (Hypothesis 2, Fig. 2). The largest differences between understory and overstory trees were observed in annual fluctuation in wood density, BAI and in $\mathrm{K}_{\text {ring }}$ which is strongly related to BAI. Through wood density adjustments, overstory trees may modulate their water transport capacity with regard to annual growth conditions (Stratton et al. 2000; Anderegg and Meinzer 2015). The relationship between BAI and wood density reflects hydraulic adjustments in many situations (Preston et al. 2006), but it can also reflect developmental constraints, such as fast cambial growth involving shorter cell-wall thickening stages (Cuny et al. (2012) on gymnosperms) that produce thinner cell walls, or thinner slowly growing stems that require mechanically stiffer and stronger wood (Lei et al. 1997). Our finding of the relatively constant xylem structure and potential specific conductivity suggests that the understory trees, in their less fluctuating environment, did not receive sufficient signals to adjust xylem structure from year to year (Fonti et al. 2010), and/or the trees' reactions were constrained 
Fig. 3 Mean ( \pm SE) of xylem traits $(\mathbf{a}, \mathbf{c}, \mathbf{e})$ : basal area increment (BAI), vessel diameter (VD) and vessel frequency (VF); and potential hydraulic performances $(\mathbf{b}, \mathbf{d}, \mathbf{f})$ : vessel conductivity-weight $\left(\mathrm{D}_{\mathrm{HP}}\right)$, potential specific hydraulic conductivity $\left(\mathrm{K}_{\mathrm{S}}\right)$ and ring conductivity $\left(\mathrm{K}_{\text {ring }}\right.$ ) of acclimated (green), understory suppressed (black, dotted lines) and understory released (yellow) saplings. The vertical dotted line shows the canopy release of released saplings in January 2005

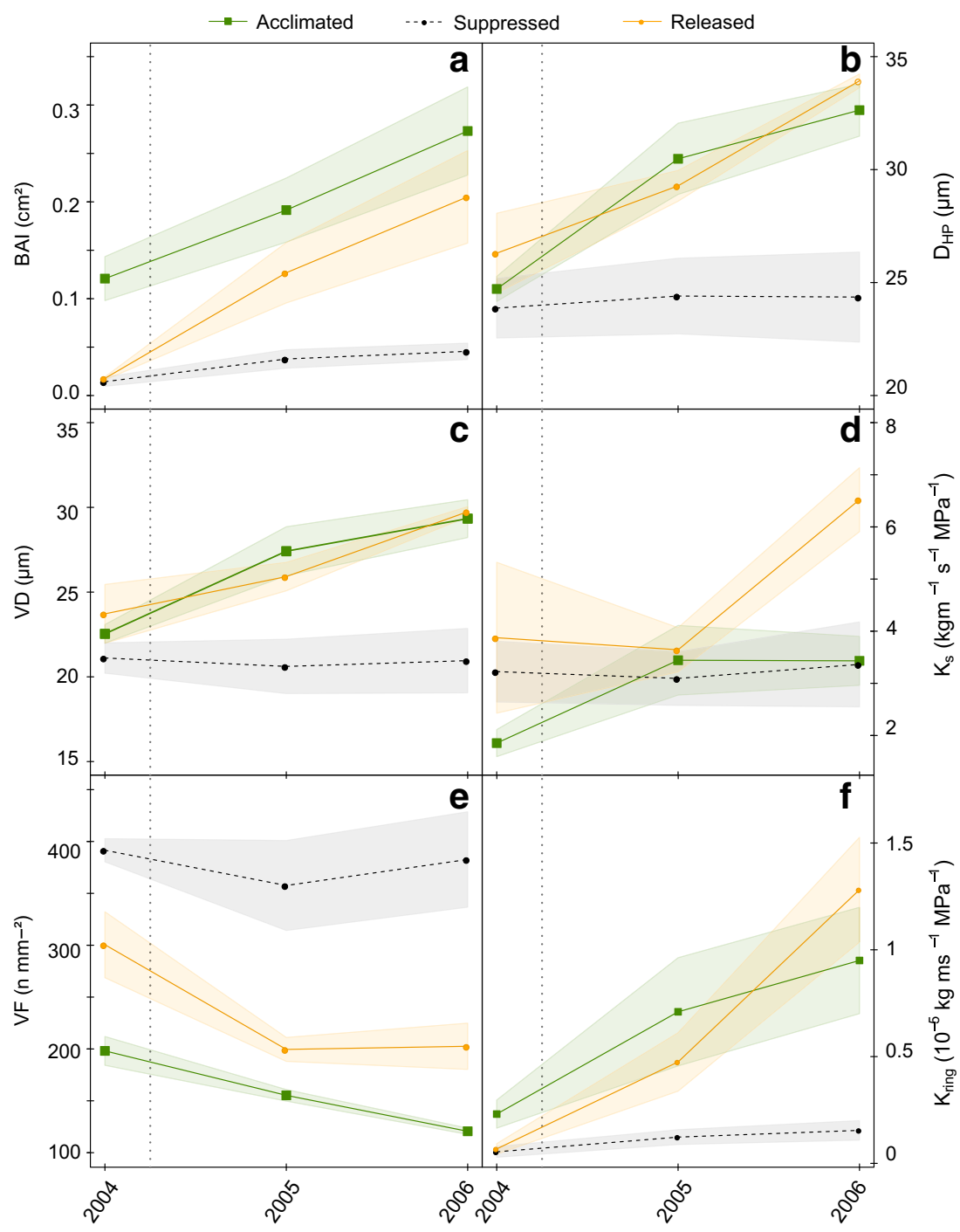

by a limited growth potential. In contrast, the larger overstory trees, in their more fluctuating environments, showed adjustments of their BAI and potential water transport ability each year.

\subsection{Effects of canopy release on xylem traits of large trees}

After understory trees are released, one would expect xylem adjustments reflecting the acclimation to the new environmental conditions. Contrary to our hypothesis, xylem structure and

Table 4 Kruskal and Wallis test ( $p$-value) for overall treatment effects (acclimated, understory released, understory suppressed) on xylem structural traits and hydraulic performances for saplings and for each year

\begin{tabular}{lllllll}
\hline Year & BAI & VD & VF & $\mathrm{D}_{\mathrm{HP}}$ & $\mathrm{K}_{\mathrm{s}}$ & $\mathrm{K}_{\text {ring }}$ \\
\hline 2004 & 0.0238 & n.s & 0.0016 & n.s & n.s & 0.0458 \\
2005 & 0.0231 & 0.0308 & 0.0073 & 0.0435 & n.s & 0.0373 \\
2006 & 0.0210 & 0.0244 & 0.0073 & 0.0231 & 0.0373 & 0.0154 \\
\hline
\end{tabular}

potential hydraulic conductivity of released understory trees approached but did not reach those of overstory trees, even 6 years after release (Hypothesis 3). Although potential treering conductivity of released trees was far from that of overstory trees and was probably limited by tree size (Poorter et al. 2010; Fan et al. 2012), all xylem traits as well as basal area growth remained stable after 2 years. Changes that occurred during the first 2 years post-release were apparently sufficient to supply the main hydraulic demands for tree survival, although we are unable to conclude whether and to what extent hydraulic properties actually limited tree growth after release. It is difficult to discuss the dynamics and duration of the acclimation of hydraulic properties because existing studies focused in general on the initial few years after canopy release in saplings or branches (Maherali et al. 1997; Hoffmann and Schweingruber 2002; Lemoine et al. 2002b; Gebauer et al. 2014).

Observed increases in $\mathrm{D}_{\mathrm{HP}}$ after canopy release may be related to a higher irradiance (Barigah et al. 2006; Hacke 2014) and wind movements in the foliage that increase the potential evapotranspiration: the wider vessels would support 
an increased demand while limiting the increase of tension in the xylem sap. However, an increase in $\mathrm{D}_{\mathrm{HP}}$ was compensated for by lower vessel frequency, so that at the tissue scale, potential hydraulic conductivity $\left(\mathrm{K}_{\mathrm{S}}\right)$ did not change. This observation may seem contradictory, with large changes observed in the xylem anatomy of beech saplings after canopy release and may be related to differences in tree size, as discussed below.

\subsection{Saplings vs large trees}

Even if the relative change in $\mathrm{K}_{\text {ring }}$ after release was similar in saplings and in large trees, the contribution of $\mathrm{K}_{\mathrm{S}}$ to $\mathrm{K}_{\text {ring }}$ release-induced changes was significant only in saplings (hypothesis 4, Table 3). This indicates that the gain of sapwood area with same intrinsic property $\left(\mathrm{K}_{\mathrm{S}}\right)$ may be sufficient to sustain the increased evaporative demand in large trees, whereas saplings equally rely on adjustments in both the tissue quantity $(\mathrm{BAI})$ and quality (especially $\mathrm{D}_{\mathrm{HP}}$ ). This difference in the nature of the transport adjustment in saplings and large trees may be partly explained by the difference in the relative contribution of one new growth ring in a species such as beech with its diffuse-porous wood and deep sapwood in which sap flow occurs throughout many growth rings (Granier et al. 2000; Luttschwager and Remus 2007; Dalsgaard et al. 2011): the effect of one ring could be much greater in the sapling than the large tree.

Other potential factors could contribute to the observed differences between released large trees and saplings that include differences in water storage and release, relative change in water path length, and specific trajectories of xylem adjustments. Due to their size, large trees may have a greater reliance on water storage and conductivity of older rings (Phillips et al. 2003) than saplings. This hypothesis is obviously only valid for species with wide sapwood area, and cannot be generalized for species like oak, known particularly to rely on the last growth ring to ensure sap flow. In fact, Collet et al. $(2001,2011)$ reported a 2-years-differed recovery of axial growth in saplings. As the radial growth rate increases, height increment relative to the total height could be larger in saplings than in large trees, increasing the water path length as well. Consequently, a relatively larger increase in $\mathrm{D}_{\mathrm{HP}}$ could help saplings to partially offset this effect.

\section{Conclusion}

Large understory Fagus sylvatica trees display lower specific hydraulic conductivity and ring conductivity than overstory trees, despite their more stable growth environment. We suggest that these differences are driven by the larger hydraulic constraints of overstory trees because of their geometry (longer path lengths and higher canopies) and their growth environment (higher VPD and more light, leading to higher rates of transpiration). Overstory trees presented inter-annual fluctuations in growth, specific conductivity, and wood density that could reflect continuous adjustments of their water transport capacity in response to their more fluctuating environments.

After canopy release by thinning, the xylem anatomy of the large understory trees was modified, stabilizing and approaching the trait values of the overstory trees without ever reaching them. The opposing effects of increased vessel diameter and decreased vessel frequency on conductivity compensated for each other in that there was no significant change in potential specific conductivity after canopy release. The gain in radial growth was sufficient to significantly increase potential stem overall performance (ring conductivity) without modifying the potential specific conductivity. This result contrasts with the saplings, for which the increase in conductivity was equally due to radial growth and changes in potential specific hydraulic conductivity (which resulted mainly from an increase in hydraulic diameter). We suggest that this result is due to a dimensional effect, the relatively larger contribution to the potential water transport of a structure via a new growth increment added to a small vs a large pre-existing structure. We emphasize that this result may be applicable only to species with considerable sapwood width that are known to use many growth rings for transport (e.g., not for ring-porous species). Further experiments on acclimation after canopy release in species with different wood types, sapwood widths, and radial sap flow patterns could yield interesting information on the role of xylem structure in tree hydraulic performance.

Acknowledgements The authors thank Daniel Rittié (INRA, Nancy) for growth measurements, Maryline Harroué (INRA, Nancy) for her assistance in anatomy experimentations, Blandine Caquet for sapling data assessment and her external help, and Mathieu Dassot (EcoSustain, Nancy) for his external help.

\section{Compliance with ethical standards}

Funding This work was supported by Office National des Forêts (convention ModelFor). The work is supported by the French National Research Agency (ANR) as part of the "Investissements d'Avenir" program (ANR-11-LABX-0002-01, Lab of Excellence ARBRE).

\section{References}

Anderegg WRL, Meinzer FC (2015) Wood anatomy and plant hydraulics in a changing climate. In: Hacke $U$ (ed) Functional and ecological xylem anatomy. Springer International Publishing, Cham, pp 235253

Aussenac G (2000) Interactions between forest stands and microclimate: Ecophysiological aspects and consequences for silviculture. Ann For Sci 57:287-301. doi:10.1051/forest:2000119

Badel E, Ewers FW, Cochard H, Telewski FW (2015) Acclimation of mechanical and hydraulic functions in trees: impact of the 
thigmomorphogenetic process. Front Plant Sci 6:266. doi:10.3389/ fpls.2015.00266

Barigah TS, Ibrahim T, Bogard A, Faivre-Vuillin B, Lagneau LA, Montpied P, Dreyer E (2006) Irradiance-induced plasticity in the hydraulic properties of saplings of different temperate broadleaved forest tree species. Tree Physiol 26:1505-1516. doi:10. 1093/treephys/26.12.1505

Bréda N, Granier A, Aussenac G (1995) Effects of thinning on soil and tree water relations, transpiration and growth in an oak forest (Quercus Petraea (Matt.) Liebl.) Tree Physiol 15:295-306. doi:10. 1093/treephys/15.5.295

Caquet B, Barigah TS, Cochard H, Montpied P, Collet C, Dreyer E, Epron D (2009a) Hydraulic properties of naturally regenerated beech saplings respond to canopy opening. Tree Physiol 29:13951405. doi:10.1093/treephys/tpp067

Caquet B, Montpied P, Dreyer E, Epron D, Collet C (2009b) Response to canopy opening does not act as a filter to Fagus sylvatica and Acer $\mathrm{sp}$. Advance regeneration in a mixed temperate forest. Ann For Sci 67(1):105

Colin F, Sanjines A, Fortin M, Bontemps J-D, Nicolini E (2012) Fagus sylvatica trunk epicormics in relation to primary and secondary growth. Ann Bot 110:995-1005. doi:10.1093/aob/mes178

Collet C, Lanter O, Pardos M (2001) Effects of canopy opening on height and diameter growth in naturally regenerated beech seedlings. Ann For Sci 58:127-134. doi:10.1051/forest:2001112

Collet C, Fournier M, Ningre F, Hounzandji AP-I, Constant T (2011) Growth and posture control strategies in Fagus sylvatica and Acer pseudoplatanus saplings in response to canopy disturbance. Ann Bot 107:1345-1353. doi:10.1093/aob/mcr058

Cuny HE, Rathgeber CBK, Lebourgeois F, Fortin M, Fournier M (2012) Life strategies in intra-annual dynamics of wood formation: example of three conifer species in a temperate forest in north-east France. Tree Physiol 32:612-625. doi:10.1093/treephys/tps039

Dalsgaard L, Mikkelsen TN, Bastrup-Birk a. (2011) Sap flow for beech (Fagus sylvatica L.) in a natural and a managed forest-effect of spatial heterogeneity. J Plant Ecol 4:23-35. doi:10.1093/jpe/rtq037

Delagrange S, Messier C, Lechowicz MJ, Dizengremel P (2004) Physiological, morphological and allocational plasticity in understory deciduous trees: importance of plant size and light availability. Tree Physiol 24:775-784. doi:10.1093/treephys/24.7.775

Eilmann B, Sterck F, Wegner L, De Vries SMG, Von Arx G, Mohren GMJ, Den Ouden J, Sass-Klaassen U (2014) Wood structural differences between northern and southern beech provenances growing at a moderate site. Tree Physiol 34:882-893. doi:10.1093/treephys/ tpu069

Fajardo A (2016) Wood density is a poor predictor of competitive ability among individuals of the same species. For Ecol Manag 372:217225. doi:10.1016/j.foreco.2016.04.022

Fan ZX, Zhang SB, Hao GY, Ferry Slik JW, Cao KF (2012) Hydraulic conductivity traits predict growth rates and adult stature of 40 Asian tropical tree species better than wood density. J Ecol 100:732-741. doi:10.1111/j.1365-2745.2011.01939.x

Fonti P, Von Arx G, García-González I, Eilmann B, Sass-Klaassen U, Gärtner H, Eckstein D (2010) Studying global change through investigation of the plastic responses of xylem anatomy in tree rings. New Phytol 185:42-53. doi:10.1111/j.1469-8137.2009.03030.x

Fournier M, Chanson B, Thibaut B, Guitard D (1994) Mesures des déformations résiduelles de croissance à la surface des arbres, en relation avec leur morphologie. Observations sur différentes espèces. Ann des Sci For 51:249-266

Gartner BL (1991) Stem hydraulic properties of vines vs. shrubs of western poison oak, Toxicodendron Diversilobum. Oecologia 87:180 189

Gasson P (1985) Automatic measurement of vessel lumen area and diameter with particular reference to pedunculate oak and common beech. IAWA Bull 6:219-237
Gebauer R, Volařík D, Urban J, Børja I, Nagy NE, Eldhuset TD, Krokene P (2014) Altered light conditions following thinning affect xylem structure and potential hydraulic conductivity of Norway spruce shoots. Eur J For Res 133:111-120. doi:10.1007/s10342-0130747-5

Granier A, Biron P, Lemoine D (2000) Water balance, transpiration and canopy conductance in two beech stands. Agric For Meteorol 100: 291-308. doi:10.1016/S0168-1923(99)00151-3

Hacke UG (2014) Irradiance-induced changes in hydraulic architecture. Botany 92:437-442. doi:10.1139/cjb-2013-0200

Hajek P, Kurjak D, von Wühlisch G, Delzon S, Schuldt B (2016) Intraspecific variation in wood anatomical, hydraulic and foliar traits in ten European beech provenances differing in growth yield. Front Plant Sci 7:791. doi:10.3389/fpls.2016.00791

Hartmann H, Messier C (2011) Interannual variation in competitive interactions from natural and anthropogenic disturbances in a temperate forest tree species: implications for ecological interpretation. For Ecol Manag 261:1936-1944. doi:10.1016/j.foreco.2011.02.018

Hoffmann S, Schweingruber FH (2002) Light shortage as a modifying factor for growth dynamics and wood anatomy in young deciduous trees. IAWA J 23:121-141

IUSS Working Group WRB (2014) World reference base for soil resources 2014. International soil classification system for naming soils and creating legends for soil maps

Klopcic M, Boncina A (2010) Patterns of tree growth in a single tree selection silver fir-European beech forest. J For Res 15:21-30. doi:10.1007/s10310-009-0157-1

Lei H, Gartner BL, Milota MR (1997) Effect of growth rate on the anatomy, specific gravity, and bending properties of wood from 7-yearold red alder (Alnus Rubra). Can J For Res 27:80-85. doi:10.1139/ x96-165

Lemoine D, Cochard H, Granier A (2002a) Within crown variation in hydraulic architecture in beech ( Fagus Sylvatica L): evidence for a stomatal control of xylem embolism. Ann For Sci 59:19-27. doi:10. 1051/forest:2001002

Lemoine D, Jacquemin S, Granier A (2002b) Beech ( Fagus sylvatica L .) branches show acclimation of xylem anatomy and hydraulic properties to increased light after thinning. Ann For Sci 59:761-766

Löf M, Bolte A, Welander NT (2005) Interacting effects of irradiance and water stress on dry weight and biomass partitioning in Fagus sylvatica seedlings. Scand J For Res 20:322-328. doi:10.1080/ 02827580500201593

Luttschwager D, Remus R (2007) Radial distribution of sap flux density in trunks of a mature beech stand. Ann For Sci 64:431-438. doi:10. 1051/forest

Maherali H, DeLucia EH, Sipe TW (1997) Hydraulic adjustment of maple saplings to canopy gap formation. Oecologia 112:472-480. doi: $10.1007 / \mathrm{s} 004420050334$

Matjaž Č, Primož S (2010) Root distribution of under-planted European beech (Fagus sylvatica L.) below the canopy of a mature Norway spruce stand as a function of light. Eur J For Res 129:531-539. doi: 10.1007/s10342-009-0352-9

McCulloh K, Sperry JS, Lachenbruch B, Meinzer FC, Reich PB, Voelker S (2010) Moving water well: comparing hydraulic efficiency in twigs and trunks of coniferous, ring-porous, and diffuse-porous saplings from temperate and tropical forests. New Phytol 186:439-450. doi:10.1111/j.1469-8137.2010.03181.x

McCulloh KA, Johnson DM, Petitmermet J, McNellis B, Meinzer FC, Lachenbruch B (2015) A comparison of hydraulic architecture in three similarly sized woody species differing in their maximum potential height. Tree Physiol 35:723-731. doi:10.1093/treephys/ tpv035

Mothe F, Duchanois G, Zannier B, Leban J-M (1998) Analyse microdensitométrique appliquée au bois: méthode de traitement des données utilisée à l'INRA-ERQB (progamme Cerd). Ann For Sci 55:301-313 
Nicolini E, Chanson B, Bonne F (2001) Stem growth and epicormic branch formation in understorey beech trees (Fagus sylvatica L.) Ann Bot 87:737-750. doi:10.1006/anbo.2001.1398

Ningre F, Cordonnier T, Piboule A (2011) Typologie et réactivité des perches de hêtre en forêt hétérogène. Forêt Wallonne 111:16-25

Parker GG, Lowman MD, Nadkarni NM (1995) Structure and microclimate of forest canopies. In: Lowman MD, Nadkarni NM (eds) Forest canopies. Academic, San Diego, pp 73-106

Petritan AM, von Lupke B, Petritan IC (2009) Influence of light availability on growth, leaf morphology and plant architecture of beech (Fagus sylvatica L.), maple (Acer pseudoplatanus L.) and ash (Fraxinus excelsior L.) saplings. Eur J For Res 128:61-74. doi:10. 1007/s10342-008-0239-1

Phillips NG, Ryan MG, Bond BJ, McDowell NG, Hinckley TM, Cermák J (2003) Reliance on stored water increases with tree size in three species in the Pacific northwest. Tree Physiol 23:237-245. doi:10. 1093/treephys/23.4.237

Poorter L, McDonald I, Alarcón A, Fichtler E, Licona J-C, Peña-Claros M, Sterck F, Villegas Z, Sass-Klaassen U (2010) The importance of wood traits and hydraulic conductance for the performance and life history strategies of 42 rainforest tree species. New Phytol 185:481492. doi:10.1111/j.1469-8137.2009.03092.x

Preston KA, Cornwell WK, JL DN (2006) Wood density and vessel traits as distinct correlates of ecological strategy in 51 California coast range angiosperms. New Phytol 170:807-818. doi:10.1111/j.14698137.2006.01712.x

Purba CYC, Noyer E, Ruelle J, Dlouhá J, Karlinasari L, Fournier M (2015) Growth stresses in old beech poles after thinning: distribution and relation with wood anatomy. J Indian Acad Wood Sci 12:37-43. doi:10.1007/s13196-015-0142-6

R Core Team (2015) R: A language and environment for statistical computing. R Found. Stat. Comput

Rentch JS, Schuler TM, Nowacki GJ, Beane NR, Ford WM (2010) Canopy gap dynamics of second-growth red spruce-northern hardwood stands in West Virginia. For Ecol Manag 260:1921-1929. doi: 10.1016/j.foreco.2010.08.043

Schuldt B, Knutzen F, Delzon S, Jansen S, Hilmar M (2016) How adaptable is the hydraulic system of European beech in the face of climate change-related precipitation reduction? New Phytol 210:443-458. doi:10.1111/nph.13798

Steppe K, Lemeur R (2007) Effects of ring-porous and diffuse-porous stem wood anatomy on the hydraulic parameters used in a water flow and storage model. Tree Physiol 27:43-52. doi:10.1093/ treephys/27.1.43

Stojnic S, Sass-Klassen U, Orlovic S, Matovic B, Eilmann B (2013) Plastic growth response of european beech provenances to dry site conditions. IAWA J 34:475-484. doi:10.1163/22941932-00000038

Stratton L, Goldstein G, Meinzer FC (2000) Stem water storage capacity and efficiency of water transport: their functional significance in a Hawaiian dry forest. Plant Cell Environ 23:99-106. doi:10.1046/j. 1365-3040.2000.00533.x

Tyree MT, Zimmermann MH (2002) Xylem structure and the ascent of the sap. Springer, Berlin Heidelberg

Webster CR, Lorimer CG (2005) Minimum opening sizes for canopy recruitment of midtolerant tree species: a retrospective approach. Ecol Appl 15:1245-1262 